\title{
The case for clinical scholarship
}

Frank S. Bloch*

\section{Introduction}

There is an inherent tension in legal education between its academic and professional missions, sometimes characterised as a conflict between theory and practice. A theory-practice tension is not unique to legal education, of course; often in professional education there are deep differences of opinion concerning the relative importance of academic inquiry and research, on the one hand, and practical training and service delivery, on the other. ${ }^{1}$ This tension is especially salient with respect to modern legal education, however, because the recent advent of clinical legal education presents the legal academy with a unique opportunity to cut across these traditional lines of conflict.

Lines between theory and practice have been blurred considerably in law teaching already, with the spreading influence of clinical legal education around the world. ${ }^{2}$ In this article, I address the implications of this trend on legal scholarship - the aspect of legal academia where theory-practice tensions tend to be strongest. Following a brief discussion of clinical education's still uncertain place in the legal academy, I turn to the role of legal scholarship and the potential contributions of clinical education to legal academic literature. Rejecting the strongest criticisms voiced by some clinicians to the effect that scholarship adds little or no value to the primary mission of legal education, which is the training of future lawyers, I explore the many facets of an emerging "clinical scholarship" informed by clinical practice. I also reject the notion that scholarship is less important for clinicians than for other law faculty, by making the case that clinical scholarship

* Professor of Law, Vanderbilt U niversity Law School (U SA ). This article is based on a paper presented by the author at the First International Journal of Clinical Legal Education Conference, held at the Institute of A dvanced Legal Studies, U niversity of London in June-J uly 2003.

1 M edical education is a prime non-law example See Lelia B. Helms, Charles M. H elms, Selden E. Biggs, Litigation in $M$ edical Education: Retrospect and Prospect, 11 J. Contemp. Health L. \& Pol'y 317,320 (1995) (discussing the "complex interdependence of medical education, research, and patient care activities" as "one of the hallmarks of academic medicine"); A braham Flexner, M edical Education in the $U$ nited States and $C$ anada ( $C$ arnegie Found. Bull. N 0. 4, N ew York, 1910). A nother is the field of education. See generally Leo S. Shulman, Theory, Practice, and the Education of Professionals, 98
Elementary Sch. 511 (1998). See also D onald A. Schon, Educating the Reflective Legal Practitioner, 2 Clinical L. Rev. 231, 233 (1995) (discussing the distinction between the theory of the classroom and the reality of practice in professional education, particularly legal education).

2 The very existence of this journal is an indication of clinical education's increasing international influence. Texts on clinical law teaching around the world offer further support. See, eg., G ary Bellow \& Bea M oulton, The Lawyering Process: $M$ aterials for Clinical Instruction in Advocacy (1978) (U nited States) (hereinafter The Lawyering Process); $M$ arlene L e Brun $\&$ Richard Johnson, The Q uiet (R)evolution: Improving Student Learning in Law (1994) (A ustralia and Canada); Clinical Legal Education (N.R. M adhava M enon, ed. 1998) (India). 
strengthens clinical legal education by helping advance its two main goals of improving the quality of law practice and enhancing the public role of the profession.

A s a clinical law teacher based in the $U$ nited States, my approach to these issues naturally reflects developments in my home country - and much of what I say in this article comes from that perspective. ${ }^{3}$ There are, however, many common points of reference among clinical law teachers around the world on most of the basic tenets of clinical legal education. M oreover, clinical education is still a "work in progress," even in those countries where it is most firmly established. A s a result, there is much to be learned across national and regional lines. Indeed, wide differences in what is meant by clinical legal education around the world and wide variation in the extent to which it has gained a role in legal education help make the case for clinical scholarship worldwide As Neil Gold said in the inaugural issue of this journal, clinical legal education "knows no jurisdictional boundaries, nor is it culturally limited in its application... A $n$ international journal promotes the study of and reflections on [clinical legal education] in a comparative or crossjurisdictional way." 4

\section{Clinical Education and the Legal Academy}

In its most basic form, clinical legal education has two complementary aims: promoting professional skills training, thereby improving the quality of law practice; and supporting law school involvement in public service, thereby raising standards of lawyer professional and public responsibility. Typically, clinical programs engage law students in experiential learning of various lawyering skills and values through active participation in some type of public service activity, such as a legal aid clinic. To those unfamiliar with legal education, this must seem anything but revolutionary. Of course law schools should direct some of their resources to training law students how to become lawyers - and to appreciate personally the public role of the profession they are about to enter. But clinical legal education has faced barriers to entry into the legal academy, to one degree or another, throughout the world.

$U$ ntil relatively recently most lawyers in the $U$ nited States and other former British colonies were trained in the distinctively non-academic settings of law offices and chambers. ${ }^{5} \mathrm{~N}$ onetheless, ever since lawyer training - and perhaps more importantly, law teachers - moved to the world of academia, university-based law faculty have tended to orient the law school curriculum and their broader institutional agendas more toward academics and theory than professionalism and practice. A $n$ important example from the $U$ nited States of this academic orientation of law study is the famous Langdellian revolution at Harvard Law School in the 1850s - and its survival to an astonishing degree up to the present. At the heart of Christopher Columbus Langdell's case

3 I have the benefit, however, of having worked for many years with clinical colleagues in India. For some insights I have gained from that experience, see Frank $\mathrm{S}$. Bloch \& I qbal S. Ishar, L egal A id, Public Service and C linical L egal Education: Future D irections From India and the U nited States, 12 M ich. J. Int'I L. 92 (1990).

$4 \mathrm{~N}$ eil Gold, Why $\mathrm{N}$ ot an International Journal of Clinical Legal Education?, 1 Intl'l J. C linical L. Educ. 7, 12 (2000).

5 See $\mathrm{N}$ ickolas J. James, $\mathrm{A}$ Brief $\mathrm{H}$ istory of $\mathrm{C}$ ritique in A ustralian Legal Education, 24 M elb. U. L. Rev. 965,
966 (2000) (" $U$ ntil the latter half of the 19th century aspiring lawyers in A ustralia were trained by more experienced practitioners in accordance with the apprenticeship model imported from England."); John E. Douglass, Between Pettifoggers and Professionals: Pleaders and practitioners and the Beginnings of the Legal Profession in Colonial M aryland, $39 \mathrm{Am}$. J. Legal Hist. 359, 384 (1995) (noting that colonial lawyers were trained in lawyers' chambers and that "it was out of lawyers' chambers that A merica's early law schools developed." ). 
method of instruction was his belief in the primacy of the law and in the ability to deduce law from given hypothetical facts. Legal education was to focus on case law, from which legal principles could be found and understood; law teachers following this approach do not concede, and therefore do not address in any way, other realities that might influence how law and legal rules develop. 6

Hailed at the time as a scientific approach to the law, the case method of law teaching resulted in a domination of textbook and classroom legal education with a top-down view of the law. ${ }^{7}$ The concentration of virtually all instruction and scholarship on doctrine as developed by appellate courts led in turn to an academic perspective on law that was largely removed from the real world of law practice As a practical matter, it pushed any interest in law practice so far into the background that the idea of practical training seemed out of place in law school - except, perhaps, via a moot court appellate argument. The outlet for legal education was a "law" school, not a "lawyer" school.8

This does not mean to say that U S law schools had abandoned the profession completely. O $\mathrm{n}$ the contrary; law schools in the U nited States have always been, above all, professional schools. U nlike some other countries, where law studies often represent a choice of discipline for one's higher education rather than a commitment to enter the legal profession, ${ }^{9}$ virtually all U S law students go to law school after four years at university specifically in order to qualify for the bar examination and, ultimately, to enter the practice of law. Q uite pragmatically and regardless of the academic and theoretical orientation of their faculties, all U S law schools have al ways offered, and will continue to offer, a core curriculum designed to fulfil that goal. Indeed, the case method and the focus on doctrine in legal scholarship that went with it had strong, albeit narrowly limited, professional training roots. $10 \mathrm{~A}$ s Judge (formerly Professor) Richard Posner has observed: "It used to be that law professors were in the university but of the legal profession... The job of the professor was to produce knowledge useful to practitioners. To be useful it had to have a credible source and to be packaged in a form the practitioner could use. The source was the law professor viewed as a superior lawyer." 11

W hether simply an accommodation to its new academic setting or a sign of its insecurity in the academy, legal education in the U nited States moved more-or-less steadily away from its preparation-for-practice roots through the mid-twentieth century. The medium of instruction for

6 See generally, D ennis Patterson, Langdell's L egacy, 90 N W. U. L. Rev. 196 (1995).

7 A s one commentator noted recently, "M odern critics have pointed out that $L$ angdell ignored the realities of the law, that by limiting his focus to the few general principles found in selected cases, he squeezed law into a few preconceived and artificial categories. In addition, the case method vastly overemphasised the appellate courts' importance in the legal system." A lexander Scherr, Lawyer and Decisions: A M odel of Practical J udgment, 47 Vill. L. Rev. 161, 167 n.18 (2002).

8 This point was captured in the title of perhaps the most famous early article championing clinical education: J erome $\mathrm{F}$ rank, Why $\mathrm{N}$ ot a C linical Lawyer-School?, 81 U. Pa. L. Rev. 907 (1933). In a stunning critique of Langdell and his case method, Frank observed: "The lawyer-client relation, the numerous non-rational factors involved in persuasion of a judge at a trial, the face-toface appeals to the emotions of juries, the elements that go to make up what is loosely known as the 'atmosphere' of a case - everything that is undisclosed in judicial opinions - was virtually unknown (and was therefore meaningless) to $L$ angdell. A great part of the realities of the life of the average lawyer was unreal to him." Id. at 908 .

9 India is an example of a country where many law students have no intention whatsoever to practice law.

10 Indeed, some practice-oriented critics of current highly interdisciplinary legal scholarship yearn for a return to the "good old days" of more accessible (and practicerelevant) doctrinal writing. See note 51 infra.

11 Richard A. Posner, 0 vercoming Law 82-83 (1995). 
reaching legal education's professional training goal had become, to the point of near exclusivity, appellate court opinions and scholarship that analysed those opinions. The effect of this was not lost on the legal profession; among the reasons put forward for written codes of professional ethics in the early 1900s was "an acknowledgement of a changed legal profession, a profession with far more lawyers, differing in class and educational background, and trained in the law through law school instead of apprenticeships." $12 \mathrm{~A}$ return to some practice focus in U S legal education came with the strong growth of clinical education in the mid-1960s and early-1970s, when a number of reports were issued by the A merican Bar A ssociation, the A ssociation of A merican Law Schools, and independent academics on the tension between theory and practice in legal education - most of which criticised law schools for failing to address this problem adequately. ${ }^{13} \mathrm{~L}$ aw schools began to pick up on the idea that the curriculum could benefit from some instruction in the actual work of lawyer. ${ }^{14}$

This recognition did not surface on its own, however. The clinical education movement came out of a push at that time for a greater focus on professional responsibility and public interest practice, more so than skills instruction. 15 Virtually all of the new or expanded clinical programs that developed in the $U$ nited States during those years operated out of some form of legal aid office, typically with interrelated goals of providing legal representation to the community and increasing student awareness of their public responsibilities as lawyers. 16 Thus, the single most important catalyst for modern U S clinical legal education was the not haphazardly named Ford Foundationfunded Council on Legal Education for Professional Responsibility (CLEPR), whose president, William Pincus, observed that clinical programs and law students who participate in those programs would help "society provide more and better legal services to those who need them." 17

N ot surprisingly, clinical education has met substantial resistance from traditional legal educators al ong the way. O pposition has come on virtually all fronts: over the granting of credit for clinical courses, in limiting the status of clinical faculty, and, most important for purposes of this paper, by means of a territorial dispute over scholarship. A Ithough each of these areas of conflict has its

12 James M. A Itman, Considering the A.B.A.'s 1908 Canons of Ethics, 71 Fordham L. Rev. 2395, 2415 (2003).

13 See Jean R. Sternlight, Symbiotic L egal Theory and Legal Practice: Advocating A Common Sense Jurisprudence of Law and Practical A pplications, 50 U. M iami L. Rev. 707, 723-25 (1996).

14 There were clinical programs in the US prior to this time, but they were few and far between. For descriptions of some important early programs, see J ohn S. Bradway, The Beginning of the $L$ egal $C$ linic of the $U$ niversity of Southern California, 2 S. C al. L. Rev. 252 (1929); J ohn S. Bradway, Some Distinctive Features of a Legal A id Clinic Course, 1 U. Chi. L. Rev. 469 (1934); A lan $M$ erson, D enver L aw Students in C ourt: The First SixtyFive Years, in Clinical Education and the $L$ aw School of the Future 138 (U niv. of C hicago L aw Sch. Conference Series N 0. 20, Edmund W. K itch ed., 1970).

15 This was true not only in the $U$ nited States, but in other countries as well. See, e.g, Judith Dickson, Clinical legal Education in the 21st C entury: Still Educating for Service?, 1 Intl'l J. Clinical Legal Educ. 33, 33-34
(2000) (noting that clinical legal education developed in A ustralia, as in the $U S$, "primarily in response to an obvious lack of legal services for the poor" and that "[a] service ideal therefore underpinned the educational adventure") (emphasis in the original).

16 The times had their effect on the traditional law school curriculum as well, and new classroom courses on law and poverty were offered at a number of schools in the late 1960s and early 1970s; however, interest in those courses began to wane after reaching a peak a few years later. Examples of published teaching materials from that time include G. Cooper, C. Berger, P. D odyk, M. Paulsen, P. Schrag, and $M$. Sovern, $C$ ases and $M$ aterials on Law and Poverty (2d ed. 1973) and A. $\mathrm{L}$ aF rance, M. Schroeder, R. Bennett $\&$ W. Boyd, Law of the Poor (1973). N one of the book published in the 1970s have survived, but a new text was published in 1997. See J. N ice \& L. Trubek, C ases and M aterials on Poverty Law (1997 \& Supp. 1999).

17 William Pincus, A Small Proposal for a Big Change in Legal Education, 1970 U. Tol. L. Rev. 913, 916 (1970). 
own story to tell, I believe that the latter has been the most damaging in the long term because what lies behind the question whether scholarship belongs in clinical legal education goes deeper than protecting traditional faculty's academic turf. Depending on one's view and the definition of key terms, clinical legal education represents, to one degree or another, the professional skills and public service dimensions of the curriculum. These are vital areas of study, with potentially profound implications for the legal profession and the administration of justice. If clinicians are kept outside the mainstream of academic scholarship, this important work is effectively sidelined outside the world of ideas.

\section{What makes clinical scholarship clinical?}

A t one level, one could say that clinical scholarship is scholarship written by clinicians. A part from the circularity of the double use of the term "scholarship" that carries with it the ambiguity of the term itself, 18 this approach is subject to the criticism that it downplays - indeed, effectively eliminates the idea that clinicians as clinicians have something unique to offer in their academic wiring. A s Peter Hoffman noted in the inaugural issue of the Clinical L aw Review, "the mere fact that an article is written by a clinical teacher does not mean it is clinical scholarship." 19

Thus, clinical scholarship must be something other than scholarship written by clinicians if the term is to have any meaning. A nd the term is, indeed, meaningful. The clinical movement has succeeded in broadening the scope of legal education in at least three ways adding serious skills instruction to the curriculum, creating centres for students and faculty to engage in public-oriented law practice, and (re)introducing experiential learning to the study of law and it is on these matters that clinical faculty can most productively concentrate their scholarship. Clinicians should not let themselves be co-opted by an ailing and increasingly removed-from-practice form of legal scholarship; 20 instead, they should take the offensive by putting the "clinical" back into "clinical scholarship" and then producing it in force.

Even with a specifically clinical-oriented clinical scholarship, there are substantial differences of opinion over what direction it should take. That debate tends to divide into two camps: one that urges clinicians to concentrate their scholarship on skills, a field that has become known as "lawyering", and another that urges a concentration on law and social change The arguments over whether clinical scholarship should have a predominantly skills or public interest orientation touch on the underlying values and purposes of clinical legal education. Indeed, the contrasting views on this issue can be seen as a proxy for a debate over the heart and soul of the clinical movement when understood in the context of broader questions concerning the ultimate value of clinical scholarship. In addition to these more substantively focused lines of clinical scholarship, there is a third line that tracks the clinical movement's contribution to legal education reform. This literature addresses issues relevant to the clinical movement and its future, particularly various

18 This question - what is scholarship? - has discussed and debated outside the clinical context forever. See, e.g., Roger C . C ramton, D emystifying L egal Scholarship, 75 GEO. L.J. 1, 8 (1986).

19 Peter Toll Hoffman, Clinical Scholarship and Skills Training, 1 Clin. L. Rev. 93, 93 (1994).

20 John Elson has made this point most strongly in an influential article published in 1989. See John S. Elson,
The $C$ ase $A$ gainst $L$ egal Scholarship or, If the Professor M ust Publish, M ust the Profession Perish?, $39 \mathrm{~J}$. Legal E duc. 343 (1989) [hereinafter The $C$ ase $A$ gainst L egal Scholarship]. See also J ohn S. Elson, W hy and $\mathrm{H}$ ow the Practicing Bar M ust Rescue A merican L egal Education from the $M$ isguided Priorities of A merican Legal A cademia, 64 Tenn. L. Rev. 1135 (1997). Elson's views are discussed further infra at text accompanying notes 52-53. 
aspects of the clinical methodology. This is not really a third "camp" since virtually everyone in the clinical community agrees that writing about clinical education and clinical methods is "clinical" and this type of writing is strongly encouraged and widely read.21

The line is not always so clear, however, between writing about clinical teaching and writing about lawyering skills and/or the public role of the profession. Except at perhaps the most technical level, one cannot divorce the clinical methodology from clinical legal education's curricular and social objectives. U nderstandably, the first flow of clinical scholarship in the 1970s and early 1980s dealt largely with clinical teaching and its educational value in the law school context. But al ready then, interest in explaining and developing the methodology was tied to a broader set of interests in professional skills and professional responsibility. This integration of method and substance is seen in the following description of what the authors describe as a "burgeoning" clinical scholarship at that time:

By focusing on clinical education as a method, clinicians began to explore what clinical teachers were and should be doing, how clinical teaching methodology could be infused throughout the law school curriculum, and what the purposes and goals of clinical teaching should be. Important early examples of clinical scholarship focused on clinical methodology, what it meant for students to assume and perform the lawyer's role in the legal system, how to identify and teach the elements of various lawyering skills, how to develop and explain theories of lawyering, how to refine and improve the supervisory process, and how to incorporate experiential learning theory into clinical law teaching. 22

The key to a meaningful definition of clinical scholarship lies in the uniqueness of the clinical approach to law teaching and the study of law. Compared to traditional academics, clinical faculty has a far wider window on the legal world and their scholarship should take advantage of it for themselves, for the clinical movement, and for the larger legal community. ${ }^{23} \mathrm{~A} s$ noted above and discussed in more detail in the next two sections, that scholarship may be about skills, public interest practice, or clinical legal education itself. $W$ hat is important is that clinical legal educators take the initiative to claim their scholarship and direct it in a way that supports and advances the broader goals of the clinical movement.

\section{What is the defining subject matter: skills or public interest?}

W hen one looks at the clinical movement from a historical perspective to some extent from its earliest days, but certainly from the beginning of its modern era in the late 1960s and early 1970s the original "subject matter" of clinical legal education was essentially legal aid and public interest practice. As mentioned earlier, virtually all clinical legal education at the time took place in working legal aid clinics. The public side of lawyering was also emphasised in Gary Bellow's and

21 This can be seen by a casual review of articles published in the clinically centred Clinical Law Review and, before the Review came into existence, among the articles written by clinicians that were published in the mainstream J ournal of L egal Education.

22 M argaret $M$ artin Barry, J on $C$. D ubin, and Peter $A$ J oy, Clinical Education for the M illennium: The Third
Wave, 7 Clinical L. Rev. 1, 16-17 (2000).

23 See Richard A. Boswell, K eeping the Practice in Clinical Education and Scholarship, $43 \mathrm{H}$ astings L.J. 1187, 1193 (1992) ("A s active practitioners within the academy, [clinicians] are uniquely able to contribute to legal education's understanding of the outside world" ). 
Bea M oulton's seminal 1978 text for clinical courses, The L awyering Process. ${ }^{24} \mathrm{~A}$ Ithough at one level a systematic treatment of what lawyers do in any type of practice the major tasks examined are interviewing, case preparation and investigation, negotiation, witness examination, oral argument and counselling. The book leads students to explore most fully the decision-making process of client representation and, in particular, how lawyers own subjectivity must integrate the complex social and political dimensions of their role.25 As A lex Hurder has observed, "[t]he common thread running through [the materials in the book] is that the choices lawyers make cannot be isolated from their understanding of the legal system and its fundamental values." 26

Clinician have and will continue to write about public interest and social justice, consistent with the central role that these matters have held in clinical education from the beginning. 27 This will be the case not only because of clinician's interest in and dedication to the public role of lawyers, but also because such work is central to the teaching and professional goals of the clinical movement.28 Of course, future clinical scholarship along these lines will reflect current circumstances in the profession and the academy. Thus, as the first co-editors of the Clinical Law Review noted in their forward to the inaugural issue of the journal: "M ost of us probably would also agree that one goal of clinical teaching is to foster, and to carry on, legal practice in the public interest. But our understanding of this goal is changing, and so is our understanding of the means by which it might be achieved." 29

Some have felt recently that a more deliberate skills orientation is needed in clinical scholarship. Peter Hoffman, a leading proponent of skills-focused clinical scholarship, finds that there is relatively little scholarship devoted to skills written by clinicians because "skills training appears no longer to be a subject of importance to clinical teachers." 30 In order to correct what he sees as an imbalance in clinical education away from skills and skills-oriented clinical scholarship, he argues that skills training is the central goal of clinical education and urges clinical teachers to see themselves primarily as teaching lawyering skills. With such an adjustment of perspective, he expects that clinical education and clinical scholarship will get back on track:

24 The Lawyering Process, supra note 2.

25 For an insightful analysis of Bellow's and M oulton's approach to these issues in The Lawyering Process, see A lexander Scherr, Lawyers and D ecisions: A M odel of Practical Judgment, 47 Vill. L. Rev. 161, 183-88 (2002).

26 A lex J. H urder, The Pursuit of J ustice: $N$ ew D irections in Scholarship A bout the Practice of Law, $53 \mathrm{~J}$. Legal Educ. 167, 170 (2002).

27 See $M$ argaret $M$ artin Barry, J on C. D ubin, and Peter A . Joy, supra note 22, at 55 (acknowledging "clinical education's long-standing commitment to social justice and the inculcation of the professional values of access to justice, fairness, and non-discrimination in the legal system")

28 For recent clinical scholarship on "the social justice mission of clinical legal education," presented at the Rutgers-N ewark Law School Conference on that topic, see Jane H. A iken, Provacateurs for J ustice, 7 Clin. L.
Rev. 287 (2001); A ntoinette Sedillo Lopez, Learning Through Service in a Clinical Setting: The Effect of Specialization on Social Justice and Skills Training, 7 Clin. L. Rev. 307 (2001); Stephen L. Wizner, Beyond Skills T raining, 7 C lin. L. Rev. 327 (2001).

29 Stephen Ellmann, Isabelle R. G unning \& Randy H ertz, W hy $\mathrm{N}$ ot a Clinical Lawyer-J ournal?, $1 \mathrm{Clin}$. L. Rev. 1, 6 (1994).

30 Peter Toll H offman, supra note 19 , at 103 . H offman notes that this anti-skills bent goes beyond scholarship preferences: " $N$ ot only is there little scholarship about skills, but those conferences and workshops on clinical legal education... infrequently focus on lawyering skills as the topic of presentations." Id. A s an example, $\mathrm{H}$ offman notes that a 1994 program sponsored by the A merican A ssociation of Law Schools' Section on Clinical Legal Education "was devoted primarily to presentations on social justice and clinical legal education. $\mathrm{N}$ ot one of the scheduled presentations was directly related to skills training." Id. at 113 n.67. 
The most important consequence of considering clinical legal education as a form of skills training is that it will encourage closer examination of the skills models being taught. The more clinical teachers analyse and test the different skills models and develop new models in response, the more scholarship we will see about skills.31

Hoffman also sets out his vision of a skills-oriented clinical scholarship: it should "help lawyers improve their representation of clients and help law students prepare to practice law"; "be practical in its orientation and design"; "be grounded in experience, rather than deduced from pure theory untested by practice"; and be accessible to its intended recipients, lawyers and law students." 32

Picking up on this theme and incorporating the lawyering skills and values message of the A merican Bar A ssociation's 1992 M acCrate Report,33 Peter Joy has argued that "clinical scholarship must incorporate both skills and values in order to fulfil its purpose of benefiting clinicians and the legal profession." 34 In order to highlight the client focus that clinical legal education has brought to law teaching and has urged on the profession, Joy's definition of clinical scholarship focuses on lawyering skills and professional values in a manner "designed to improve the ability of lawyers to represent clients and to help law students prepare to represent clients." 35 Noting that much of current scholarship written by clinicians is far removed from such a focus, he charges that "clinicians are suppressing our unique perspective as both law teachers and practicing lawyers." 36

W riting about skills and practice does not necessarily lead to effective exchanges between clinical teachers and practicing lawyers; it can be highly theoretical, to the point that it can lose the professional audience. Thus, Richard Boswell has observed that "some of the recent scholarship of clinicians, while representing a significant contribution to understanding the role of law and lawyers in society, is more exclusive than inclusive... It does not speak in the language of clients, lawyers, or even judges." 37 In his view, clinical scholarship should serve as a "bridge" between the legal academy and the larger professional world:

$\mathrm{N}$ ew clinical scholarship need not supplant the critical theories of the past two decades, but could inform each constituency about the other: scholarship that focuses on what clinicians talk about and experience on a daily basis in our interactions with clients, students, lawyers, judges, social workers, legislators, and countless others; scholarship that willingly addresses and grapples with moral and ethical questions. This kind of scholarship might help to draw links between each of these important constituencies of our work. Indeed, it might well lead us to a deeper mutual understanding. 38

31 Id. at 114.

32 Id. at 114. For a discussion of $H$ offman's vision, see Peter A. Joy, Clinical Scholarship: Improving the Practice of Law, 2 Clinical L. Rev. 385, 394-97 (1996).

33 See note 55 , infra, and accompanying text.

34 Peter A. Joy, Clinical Scholarship: Improving the Practice of Law, 2 Clinical L. Rev. 385, 387 (1996).
35 Id. at 388

36 Id. at 390 .

37 Richard A. Boswell, K eeping the Practice in Clinical Education and Scholarship, $43 \mathrm{H}$ astings L.J. 1187, 1192-93 (1992).

38 Id. at 1194 . 
O ne example of current work along these lines is an international research project that seeks to bring together the legal profession, legal educators, and social scientists in order to develop a shared approach to evaluating and improving lawyer-client communications. 39

\section{Writing about clinical education}

A s mentioned earlier, any definition of clinical scholarship also encompasses writing on clinical education itself. This is perfectly natural; persons involved in a reform movement want to share (and advertise) their project in writing. M oreover, clinical teachers have been accepted most easily into the legal academy as teaching colleagues, which has helped to encourage clinicians to write about law teaching. O bjectively, this is a good thing; since the clinical movement is dedicated to reforming legal education, one can say that clinical teachers have a responsibility to write about teaching. A rticles and essays on clinical teaching methods appear regularly; much of this work has been received positively in the legal academy, reinforcing the notion that clinical education has had a transformative effect on professional training.

The volume of this work is huge and giving justice to its content is far beyond the scope of this paper. N onetheless, some examples will give a flavour of this far-reaching literature. The clinical faculty at Vanderbilt U niversity Law School published an anthology of readings for live-client clinics a number of years ago composed almost exclusively of what most clinicians would agree is clinical scholarship. 40 The first chapter of the anthology addresses the subject of live-client clinical education, and does so in two parts: one covering curricular objectives and the other covering the clinical methodology. Beginning with Jerome Frank's seminal article, W hy N ot A Clinical L awyerSchool?,41 the part on curricular objectives includes articles that map the future of clinical education in the context of its past (or lack thereof), ${ }^{42}$ reflect on the influence the $\mathrm{M}$ acCrate Report's Statement of Fundamental Skills and Values on a professional training curriculum, 43 and explore how the range of learning opportunities that can come from the supervised clinical practice 44 The part on the clinical methodology includes articles that set forth an educational context for clinical legal education, 45 criticise the actual clinical teaching that takes place, ${ }^{46}$ and offer models for clinical instruction. 47

There is, however, a dark side to this success story. A false dichotomy between teaching and scholarship that plagues legal education generally tends to be applied with special vengeance to

39 See Clark D. Cunningham, Evaluating Effective Lawyer-Client Communication: A $n$ International Project $M$ oving From Research to Reform, 67 Fordham L. Rev. 1959 (1999).

40 Clinical A nthology: Readings for Live-Client Clinics (A lex J. H urder, Frank S. Bloch, Susan L. Brooks \& Susan L. K ay eds., 1997). The editors discuss their debt to clinical scholarship in Frank S. Bloch, Susan L. Brooks, A lex J. H urder \& Susan L. K ay, Filling in 'T he L arger Puzzle': C linical Scholarship in the Wake of The L awyering Process, 10 Clinical L. Rev. 221 (2003).

41 See note 2, supra.

42 A nthony G. A msterdam, C linical L egal Education - A 21st C entury Perspective, 34 J. L egal Educ. 612 (1984).
43 Jonathan Rose, The M acC rate Report's Restatement of $L$ egal Education: The $\mathrm{N}$ eed for Reflection and $\mathrm{H}$ orse Sense, 44 J. L egal E duc. 548 (1994).

44 A nn Shalleck, Clinical Contexts: Theory and Practice in Law and Supervision, 21 N.Y.U. Rev. L. \& Soc. Change 109 (1993).

45 Frank S. Bloch, The A ndragogical Basis of Clinical Legal Education, 35 Vend. L. Rev. 321 (1982).

46 Robert C ondlin, "T astes $G$ reat, L ess Filling": T he Law School Clinic and Political C ritique, $36 \mathrm{~J}$. L egal Educ. 45 (1986).

47 M inna J. Kotkin, Reconsidering Role A ssumption in Clinical Education, 19 N. M ex. L. Rev. 185 (1989). 
clinical law teachers. 48 A rticles, or even books, that address clinical legal education are not valued in the same way as is traditional academic scholarship. Even to the extent that the issues addressed in these types of works - law school instruction and preparation for the practice of law - are recognised as important to the legal academy, writing about them is not seen as academic. This is, of course, not unique to writings on clinical legal education; downgrading writing on clinical teaching puts clinicians, in this respect at least, on a par with other law teachers who write about teaching.

Does this mean that clinicians should abandon clinical education as a subject for clinical scholarship? Is it simply a question of terminology: keep writing about clinical education, but don't call it clinical scholarship? In my opinion, the answer to both questions is a resounding "no." The clinical movement is just that - a movement - and the word needs to be spread in the coming years, particularly across national and regional boundaries. A nd because clinical education stands for much more than a novel set of course descriptions, which are properly not considered scholarly in nature, more substantial writing on clinical education deserves to share the label of clinical scholarship.

\section{Clinical scholarship, academic status, and the elusive problem of legitimacy}

Scholarship is, of course the key to professional status and personal security in the legal education; "publish or perish" is an old story at law schools and elsewhere in the academic world. For traditional academics, it is an easy either/or proposition: either you publish at a certain level of quality and quantity or you move on. A Ithough the publication requirement varies considerably from school to school, if you achieve at the expected level - often with different levels of expectation pre- and post-tenure - you enjoy continuing and relatively undifferentiated status al ong with your colleagues on the law faculty. 49 The title "law professor" is reserved for scholars, or at least persons who can pretend to be scholars, 50 and once you're in the club you're a member for life.

The role of scholarship is not so simple in the world of clinical legal education. In addition to the issues of content referred to earlier - is what clinicians write really scholarship? - one can ask quite legitimately whether clinicians should write at all. A fter all, if clinical programs are intended to counterbalance removed-from-practice classroom instruction, shouldn't clinical teachers devote themselves to practice and practice-based instruction rather than mimic their scholarship producing nonclinical counterparts?

$M$ any clinicians thus find themselves, for better or worse, off the traditional scholarship treadmill. For better, in the sense that clinical faculty can argue for a wider definition of "scholarship" than

48 For a discussion of this and another false dichotomy in clinical legal education, practical training vs. public service, see F rank S. B loch, T eaching and D oing J ustice: The Importance of Clinical L egal Education to Law Schools Facing $\mathrm{N}$ ew Global Challenges (paper presented on $8 \mathrm{M}$ arch 2003 at the Conference on $\mathrm{G}$ lobal $\mathrm{C}$ hallenges for Legal Education and $\mathrm{H}$ uman Rights T eaching, sponsored by the U K C entre for L egal Education and the $U$ niversity of Warwick).
49 Status is relatively undifferentiated for law professors in the U S since the tenure and promotion policies at most schools - unlike traditional academic departments favour early tenure decisions and simultaneous promotion of tenured faculty to full professor.

500 bviously, the correlation is not complete. But there can be no doubt that the production of scholarship is a key expected output of law faculty and a measure of their and their home institution's standing. 
their traditional academic colleagues by pointing out the broad social and professional goals of the clinical movement and the relative richness and complexities of the clinical teaching method. W orse in the sense that distinguishing between writing about clinical teaching and traditional law teaching can result in two dramatically contrasting, but equally negative, institutional consequences: rejection of the distinction by the faculty, followed by a "blood bath" at the time of promotion or tenure; or acceptance of the distinction, followed by an al most unavoidable secondclass status for the clinical program and its faculty. Just as including serious writing about clinical education within the definition of clinical scholarship is a key to keeping the "clinical" in clinical scholarship, we need to be mindful of the consequences of taking the "scholarship" out.

M y conception of clinical scholarship is simple and direct: it must be informed by the clinical experience (in other words, written by a clinician relative to his or her clinical work) and it must advance the goals of the clinical movement (certainly beyond lawyering skills and values, but not any writing that happens to be by a clinician). This may be too vague for some, but too close a definition runs the risk of marginalisation. In my opinion, for clinical scholarship to survive it must both establish its identity and at the same time combat fal se compartmentalisation. A rguing over whether clinical scholarship should focus on skills or public interest practice misses the point; both are informed by the clinical experience and both address issues important to the clinical movement. Clinical law teachers have a duty to write about the academic side of their work, whether on the lawyering process, law and society, or legal education reform. Indeed, having both the responsibility for and the opportunity to write clinical scholarship is a key to establishing clinical legal education's rightful place in the legal academy.

\section{The Case for Clinical Scholarship}

The proper place of scholarship in the legal academy is a serious question that has occupied lawyers, judges, and law faculties both in private discussions and in print over the years, and will continue to do so for a long, long while. There is no reason to review the general debate here, 51 but some mention of critiques of particular relevance to a clinical perspective on the issues is warranted before turning specifically to the case for clinical scholarship. In a widely cited article, The $C$ ase $A$ gainst L egal Scholarship, John Elson makes the simple point that typifies many clinicians' aversion to traditional legal scholarship: when law schools devote so much resources - and professors so much time and energy - to scholarship directed at obscure subjects of the professors' personal interests, they necessarily limit the amount of attention paid to the central task of educating new lawyers. 52 Specifically, Professor Elson argues:

[F ]irst, law schools have a paramount duty to educate their students for practice competence; second, law schools generally are not fulfilling that duty satisfactorily; third, the more emphasis law schools give to the production of legal scholarship, the

51 M uch of the debate over modern legal scholarship began with a widely cited and discussed 1992 article by Judge $\mathrm{H}$ arry $\mathrm{T}$. Edwards, in which he argued that the legal academy had become self-indulgent and almost irrelevant to the profession. See H arry T. Edwards, The $G$ rowing $D$ isjunction Between $L$ egal Education and the L egal Profession, 91 M ich. L. Rev. 34 (1992). For J udge Edward's comments following strong response to the article, see $H$ arry $T$. E dwards, The G rowing D isjunction
Between Legal Education and the Profession: A Postscript, 91 M ich. L. Rev. 2191 (1993) (symposium on the 1992 article). See generally Peter A . J oy, C linical Scholarship: Improving the Practice of Law, 2 Clinical. L. Rev. 385 (1996) (discussing a "growing introspection over legal scholarship and the dissonance between legal scholarship and the legal profession").

52 See John S. Elson, The C ase A gainst L egal Scholarship, supra note 20 , at $370-71$. 
less satisfactory their education for professional competence is likely to be; and, fourth, the reasons commonly asserted for the primacy of law school's scholarly mission do not justify the resulting cost to their mission of professional education. 53

Elson's argument is, in effect, a classic slicing-a-static-pie argument - but one that has a strong realistic appeal in the traditional academic setting. If his reasoning is carried over to clinical scholarship, it could suggest that clinicians not write at all - for reasons very different from those mentioned earlier in the context of clinical education and academic legitimacy: what clinicians can write about is not scholarship. However, just the opposite is true. A great strength of clinical legal education is that it embraces its tie to the "real world" of law practice. The clinical methodology gains much of its richness when students are immersed in actual lawyer work, with all of its complexities and ambiguities. The resulting exposure of clinical teachers to practice in this unique setting, both directly and through the eyes (and experience) of their students, offers them the opportunity to study the profession from a different perspective than their academic colleagues and to write about important matters that might not be written about otherwise 54 If taken up with real enthusiasm and as an integral part of their clinical practice, clinical scholars can not only bridge existing gaps between the legal academy and the legal profession, but in doing so can enrich both by shedding new light from each on the other.

I do not mean to suggest that the practice of law and the role that lawyers play in the legal process had not been written about before. N or can I say that clinicians should have an exclusive claim on the field. But there can be no doubt that the clinical movement and the growing body of clinical scholarship have expanded the scope of this work and have done so in ways that are particularly important to the future of the legal profession. Clinicians are credited in the U nited States, for example, with redefining the scope of law practice and what it means to be a "good" lawyer. Thus, the A merican Bar A ssociation's historic M acC rate Report, in which a select committee identified fourteen critical skills and values of the profession, drew heavily on the work of clinical legal education and relied to a substantial extent on clinical faculty. $55 \mathrm{~A}$ nother important contribution al ong these lines is the "Best Practices Project" at the Center on Professionalism at the U niversity of South Carolina, a project undertaken with the co-sponsorship of the Clinical Legal Education A ssociation to identify the best practices for preparing new lawyers for law practice.56

M oreover, clinicians through their scholarship have pressed their case lawyers in the field, urging greater appreciation of their insights on lawyering and application of their work on professional skills and values. By combining their academic-based appreciation of the broader roles of law and lawyers in society to gether with on-the-ground exposure to client's problems and the limits of the legal system's ability to address those problems, clinical scholarship on new approaches to lawyering has helped equip lawyers to serve better their client's needs. A prominent example is the extensive literature on client-centred lawyering. A pplied first by clinicians in the context of legal

53 Id. at 344 (citations omitted).

54 Thus, it was a pair of clinicians who opened the way for critical examination of the "lawyering process" in a highly influential book of the same name. See The Lawyering Process, supra note 2 . The Clinical Law Review published a symposium issue celebrating the twenty-fifth anniversary of the publication of the book in 2003. See Symposium, The 25th A nniversary of
Gary Bellow's and Bea M oulton's The Lawyering Process, 10 Clinical L. Rev. 1-468 (2003).

55 Section of L egal Educ. and A dmissions to the Bar, A M. Bar $A$ ss'n, L egal Education and Professional D evelopment - an Educational C ontinuum (Report of the Task Force on Law Schools and the Profession: N arrowing the G ap, 1992).

56 This project can be viewed at: http://professionalism.law.sc. edu/news.cfm\#C LEA . 
counselling, client-centredness has made its way into a wide range of work on law practice 57 A nother example is the field of "therapeutic jurisprudence," which clinicians have used to go beyond the realm of win-lose results and examine how law and how it is practiced can have can have an influence on clients' physical and psychological well being. 58

The range of what can be covered in clinical scholarship is illustrated by an important link between two major goals of clinical legal education: improving the quality of practical training in law school is itself public service In most countries there are plenty of lawyers. At the same time, there is a real shortage of good lawyers - especially in lower income communities. Lawyer incompetence is its own form of injustice; therefore, the practical training aspects of clinical legal education serve the public by improving lawyer competence through the use of experiential teaching and learning. Depending on the availability of resources and differing local rules and practices, this can include supervised "real world" legal work at law school clinics or in fieldwork placements and/or classroom work using simulated problem-based materials.

Of course improving the quality of the bar involves more than raising levels of technical competence. Clinical education also seeks to address generally the public role of law and lawyers in society and to motivate young lawyers to work for the public good. Depending again on the availability of resources and differing local social, economic, and political contexts, clinical programs bring this message home to law students by having them contribute directly to the public interest in a variety of ways. Here again, the richness of "live client" or real-world-based clinical education can lead to a unique clinical scholarship.

Gary Palm has argued, for example, that clinical scholarship should be incorporated directly into the teaching and public service missions of clinical legal education.59 A ccording to him, "the 'complete' clinical teacher is one whose collaborative work with students includes some efforts to obtain reforms to correct systemic problems which have been identified through representing individual and organisational clients directly." 60 A lthough a well-known sceptic on the subject of clinicians engaging in traditional scholarship, 61 he finds that scholarship linked to this type of "complete" clinical work - what he might call "true" clinical scholarship - adds value to the enterprise and can support the ultimate goals of the clinical movement:

For the clinical teacher who engages in such efforts to achieve systemic reform, scholarship affords a means to expand a clinical programme's efficacy by sharing

57 D. Binder \& S. Price, Legal Interviewing and Counseling: A Client-centred A pproach (1977). See also Robert D. Dinerstein, Client-centred Counseling: Reappraisal and Refinement, 32 A riz. L. Rev. 501 (1990); D onald G. Gifford, The Synthesis of Legal C ounseling and $\mathrm{N}$ egotiation $\mathrm{M}$ odels: Preserving $\mathrm{C}$ lientcentred Advocacy in the $\mathrm{N}$ egotiation Context, 34 U CLA L. Rev. 811 (1987).

58 See David B. Wexler, "Reflections on the Scope of Therapeutic Jurisprudence, 1 Psychol., Pub. Pol'y \& L. 220, 224 (1995).

59 See Gary H. Palm, Reconceptualizing Clinical Scholarship as Clinical Instruction, 1 Clinical L. Rev. 127 (1994) [hereinafter Reconceptualizing Clinical Scholarship]. See also Lucie E. W hite, Collaborative Lawyering in the Field? $0 \mathrm{n} \mathrm{M}$ apping the Paths From
Rhetoric to Practice, 1 Clinical L. Rev. 157 (1994) (describes an advanced clinical seminar at U CLA in which students investigated grassroots social initiatives and examined the types of organisations involved, the roles of lawyers in the organisations' agendas, and the inherent tensions of the work; stresses the need for critical reflection on the dynamics and process of grassroots organising, and for increased clinical scholarship).

$60 \mathrm{G}$ ary H. Palm, Reconceptualizing C linical Scholarship, supra note 59 , at 132 .

61 This view was expressed in print during his tenure as $C$ hair of the Section on C linical L egal Education of the A ssociation of A merican Law Schools. See G ary H. Palm, M essage from the $C$ hair, in A A LS Section on Clinical L egal Education, N ewsletter, Sept. 1986, at 1. 
information about successful approaches with other clinical teachers. M oreover, articles of this sort will stimulate others to come up with yet other ideas to improve clinical programs and the quality of representation of clients. 62

I mentioned earlier that clinical education is a work in progress. So is clinical scholarship. There are countless ways that the complexities of clinical practice can be matched with those of the legal profession and the academy to present interesting and worthwhile questions to consider. Take, for example, the matter of client voice. The context of clinical practice led clinical scholars to introduce client narrative in their legal scholarship, an innovation that has been followed widely by non-clinical scholars as well.63 This came naturally to clinicians not only since they focus directly on clients and clients' needs with their students in their capacity as lawyer-teachers, but also because the nuances of lawyer-client interaction is a key component of the clinical curriculum. Clinicians must continue to draw on their access to this unique perspective in order to enrich particularly clinical scholarship, but at the same time address important sensitivities this opportunity presents. Just as clinical scholars have pointed out regularly in the context of client representation that clients have and own their own voices, 64 a proper understanding of and respect for their ownership of clients' voices is indispensable to a responsible clinical scholarship. $65 \mathrm{~N}$ ot only should clients' voices, when used, be understood and credited, but they should also be representative of the appropriate community according to the issues discussed in the work. But use of client narrative in legal scholarship is itself problematic and needs to be examined in the context of the ethics of telling a client's story in print. Despite their experience in working with clients as lawyers and teachers, this is an area where clinicians may need to turn to fellow scholars (clinical or not) for guidance ${ }^{66}$

\section{Conclusion}

I do not underestimate the difficulties that clinicians face in writing serious scholarship; the life of a clinical law teacher is quite different from that of his or her traditional academic counterpart. First and foremost, for live-client clinical teachers, is the stress and on-going responsibility that goes with handling real cases. Then there are the tremendous time demands of one-on-one

62 G ary H. Palm, Reconceptualizing C linical Scholarship, supra note 59, at 132 . See also Stephen Ellmann, Isabelle R. G unning \& Randy H ertz, supra note 29 , at 2 ("Like their nonclinical colleagues, clinicians have come to see scholarship as a means of disseminating information about innovative approaches and exploring ideas that grow out of clinical teaching experiences").

63 A mong the clinicians credited with early client narrative Scholarship are A nthony A Ifieri, Clark C unningham, and L ucie W hite. See, e.g., A nthony V. A Ifieri, Speaking $O$ ut of T urn: The Story of J osephine V., $4 \mathrm{G} \mathrm{eo}$. J. L egal E thics 619 (1991); C lark D. C unningham, The L awyer as Translator, Representation as Text: Towards an Ethnography of Legal D iscourse, 77 Cornell L. Rev. 1298 (1992); Lucie W hite, Subordination, Rhetorical Survival Skills, and Sunday Shoes: $N$ otes on the Hearing of M rs. G., 38 Buff. L. Rev. 1 (1990). See generally, Binny $M$ iller, T elling Stories $A$ bout $C$ ases and Clients: The Ethics of $\mathrm{N}$ arrative, $14 \mathrm{Geo}$. J. Legal Ethics 1, 7-12 (2000).
64 See note 57, supra, and accompanying text.

$65 \mathrm{C}$ f. Robert D inerstein, C linical Education in a D ifferent Voice: A Reply to Robert Rader, 1 C linical L. Rev. 711, 711 (1995) ("many of our current discussions about clinical scholarship decry the absence (or appropriation) of client voice in clinical scholarship").

66 See Binny M iller, supra note 63 , at 4 ("the client focus of the collaborative lawyering approach suggests that legal academics need to consider whether clients should have a say in decisions about how their stories are told. Yet surprisingly, while clients are in the forefront of many law review articles, they are almost invisible in the decision making process about which story to tell or whether to tell a story at all"); id. at 5 ("W hile the ethics of scholarship literature examines the integrity of scholars' conclusions, it does not look in depth at clients as the subject of scholarship. The authors of stories about clients also sidestep the ethical issues" ). 
teaching/supervision/critique required for just about any type of clinical course. A s one clinician wrote recently, the challenges that clinical teachers face in producing written scholarship are "daunting." 67

N onetheless, clinical teachers are academic lawyers; scholarship should be what they do. Clinicians through their clinical scholarship have begun to change the way the profession looks at itself and, to some degree, what it does. Clinical scholars are, and must continue to be, active voices in the profession and society. U Itimately, the benefits of legitimacy brought about by the publication of serious clinical scholarship will also support the active, public service mission of clinical legal education. Contrasting the current distressed state of federally funded legal services in the $U$ nited States with a relatively strong and stable system of clinical education, Professor Rick W ilson notes:

The clinical legal education movement, on the other hand, by casting itself more as a fundamental component of legal education than as another means by which legal services can be provided to the poor, has been successful in accomplishing a legitimate role for itself in U.S. legal culture It is helped in this effort by the development of a body of clinical scholarship that contributes to its legitimate academic standing, as well as the fact that it has never been primarily funded by the state 68

This is "publish or perish" in a constructive sense, using the "bully pulpit" of academia to ensure a permanent place in legal education for all that clinical education has shown the legal academy it can be.

67 K imberly E. O 'L eary, Evaluating Clinical Teaching Suggestions for $\mathrm{L}$ aw Professors $W$ ho $\mathrm{H}$ ave $\mathrm{N}$ ever $\mathrm{U}$ sed the Clinical Teaching M ethod, 29 N. K Y. L. REV. 491, 511 (2002). O ther "challenges" noted by Professor L eary on a non-exclusive list include having to learn the clinical teaching methodology, writing about problems not addressed by "traditional" scholarship, not knowing the unwritten rules about scholarly writing, and dealing with political battles surrounding the clinic. Id. at
511-14. For a view of these issues from the perspectives of a legal writing instructor, see Susan P. Liemer, The Q uest for Scholarship: The Legal Writing Professor's Paradox, 80 O R. L. REV. 10072001

68 Richard J. Wilson, Three Law School Clinics in Chile, 1970-2000: Innovation, Resistance, and Conformity in the Global South, 8 CLIN ICAL L. REV. 515, 579 (2002). 